\title{
Filling the Distribution Gaps for Small Mammals in Montana
}

\author{
Prepared for: \\ USDI Bureau of Land Management, Montana State Office
}

By:

Paul Hendricks, Susan Lenard, Coburn Currier, and Bryce Maxell

\author{
Montana Natural Heritage Program \\ Natural Resource Information System \\ Montana State Library
}

April 2007

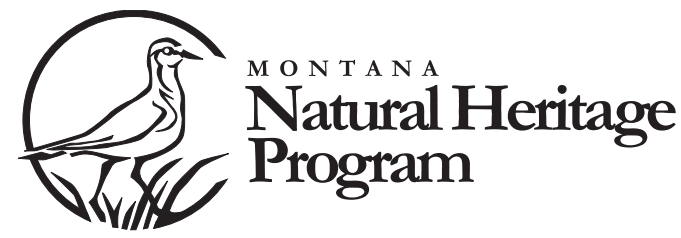





\title{
Filling the Distribution Gaps for Small Mammals in Montana
}

\author{
Prepared for: \\ USDI Bureau of Land Management, Montana State Office
}

Agreement Number:

1ESA 0100009

By:

Paul Hendricks, Susan Lenard, Coburn Currier, and Bryce Maxell
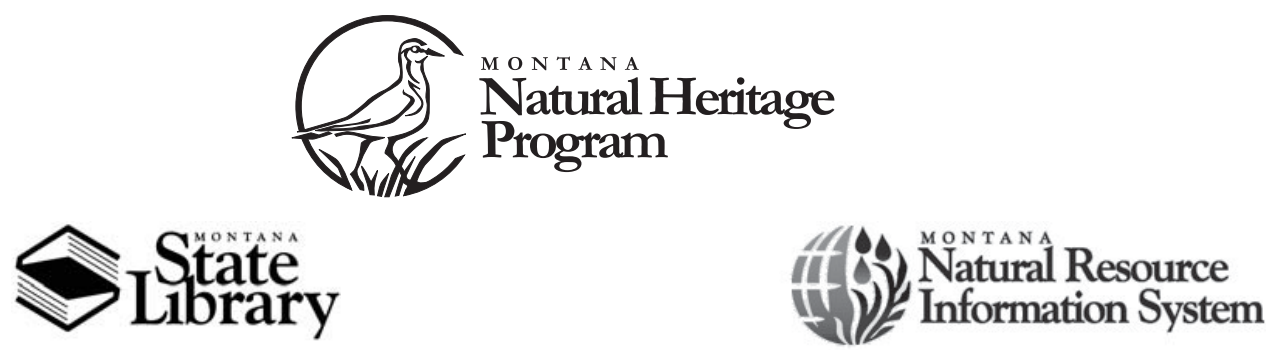

(c) 2007 Montana Natural Heritage Program

P.O. Box 201800 • 1515 East Sixth Avenue • Helena, MT 59620-1800 • 406-444-5354 
This document should be cited as follows:

Hendricks, P., S. Lenard, C. Currier and B. Maxell. 2007. Filling in Distribution Gaps for Small Mammals in Montana. A report to The USDI Bureau of Land Management, Montana State Office. Montana Natural Heritage Program, Helena, Montana 17 pages. 


\section{Executive Summary}

The Montana State Office of the BLM has designated 12 small mammal taxa (not counting four furbearers) as Sensitive Species. These include eight species or subspecies of bats, three rodents, and one rabbit. The distribution and status of small mammals throughout Montana remain poorly documented for most species. This is of conservation interest because management activities could have unintended consequences on habitats used by small mammals that are undocumented in the impacted area.

The Montana Office of the BLM recognized the need for additional documentation of small mammals on lands administered by them, and we conducted surveys across the state in 2006 to address this need. We surveyed non-randomly chosen sites for bats and small terrestrial mammals (rodents and shrews) at several locations in southwestern, central, and southeastern Montana. Areas chosen for these surveys represented significant gaps in our occurrence data. In addition, we conducted surveys for Pygmy Rabbit (Brachylagus idahoensis) in southwestern Montana during late winter 2007, focusing on determining the northern extent of their range and the connectivity with populations farther south in Beaverhead County. We gathered data on bats at 18 sites, terrestrial small mammals at 22 sites, and visited 24 sites for Pygmy Rabbit.

Eight species of bats were detected during our surveys: Big Brown Bat (Eptesicus fuscus) at two sites, Hoary Bat (Lasiurus cinereus) at 12 sites, Silver-haired Bat (Lasionycteris noctivagans) at six sites, Western Small-footed Myotis (Myotis ciliolabrum) at seven sites, Western Long-eared Myotis (M. evotis) at seven sites, Little Brown Myotis (M. lucifugus) at 11 sites, Fringed Myotis (M. thysanodes) at three sites, and Long-legged Myotis (M. volans) at seven sites. The 2006 bat surveys filled significant gaps in Montana distributions by adding 13 first county records, including six first county records for three state BLM Sensitive Species: Western Long-eared Myotis (Petroleum County), Fringed Myotis (Beaverhead, Garfield, and Petroleum counties), and Long-legged Myotis (Garfield and Petroleum counties).

Six species of terrestrial small mammals (all rodents) were captured during our surveys: Ord's Kangaroo Rat (Dipodomys ordii) at one site, Sagebrush Vole (Lemmiscus curtatus) at four sites, Olive-backed Pocket Mouse (Perognathus parvus) at three sites, Deer Mouse (Peromyscus maniculatus) at all sites, Western Harvest Mouse (Reithrodontomys megalotis) at one site, and Northern Pocket Gopher (Thomomys talpoides) at one site. Although none of the captures were first county records, some nevertheless helped filled gaps in known distributions.

Late-winter 2007 surveys documented the continued presence of Pygmy Rabbits at two sites in the Big Hole Valley not resurveyed since 1997, and also found Pygmy Rabbits at a new site near Wisdom (also in the Big Hole Valley), as well as a new site in Grasshopper Valley to the southeast of the Big Hole, indicating that connectivity in the Big Hole may continue to exist with numerous sites near Bannock and points south to Idaho. No evidence of Pygmy Rabbits was found along the eastern base of the Pioneer Mountains, or along the State Highway 43 corridor through Wise River.

The 2006-2007 surveys filled important gaps in documented distributions of bats in Montana, and provided a better definition of the northern and eastern extent of Pygmy Rabbit in the state. Existing bat records across the region clearly show that significant gaps in known distributions remain for all species, emphasizing the need for addition surveys. Large areas between the Missouri and Yellowstone rivers still lack records of any bat species, and most records from the region are from the main river corridors. Distributions for some terrestrial small mammal also show large gaps within their range extents. This is particularly the case for some relatively rare shrew species, none of which we documented, and several species of rodents. Documenting rare shrews will require special survey methods, such as extensive use of pitfall traps. 
We recommend the BLM continue surveys for bats and small mammals in eastern Montana, particularly in areas still lacking surveys, and possibly using a grid-based random sampling scheme stratified by ecoregion or Field Office that would allow for valid inferences of site occupancy rates across selected strata. This grid-based monitoring approach should be extended to all of Montana and coordinated with other partner agencies and organizations to guide effective management of terrestrial small mammals across the state. Additional surveys for Pygmy Rabbits would be useful for documenting more fully the connectivity of the Big Hole Valley populations with other populations in Montana, as well as for determining the northeastern range limit. 


\section{ACKNOWLEDGEMENTS}

We thank the State Office of the BLM for supporting this project, which helped fill gaps in the known distributions of several small mammal species in Montana. Steve Cooper, vegetation ecologist at the Montana Natural Heritage Program, provided directions to some of our small mammal survey sites. Amy Shovlain (USFS) and Kelly Bockting (BLM) provided information on Pygmy Rabbit survey locations, and Amy participated in some of the surveys. Dr. Joe Szewczak, Associate Professor of Physiology at Humboldt State
University for expert bat call analysis and training using Echolocation Call Characteristic Key. Scott Blum, assistant biologist at the Montana Natural Heritage Program, participated in field surveys in central Montana, and entered survey data into the Point Observation Database (POD), which facilitated the production of new distribution maps and the updating of element occurrence data in the Montana Natural Heritage Program's Biotics database. 


\section{Table of Contents}

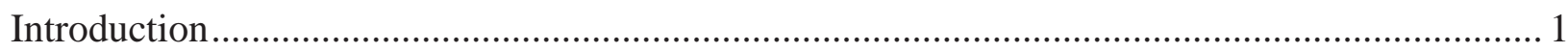

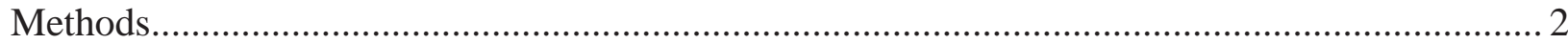

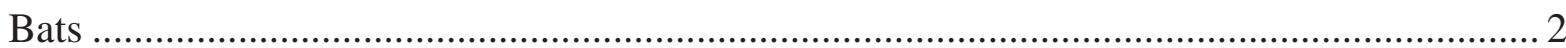

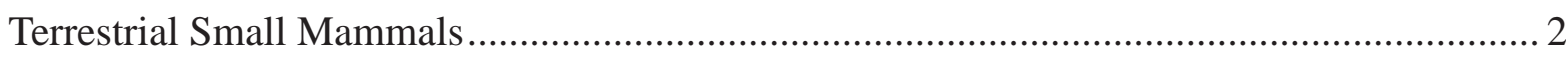

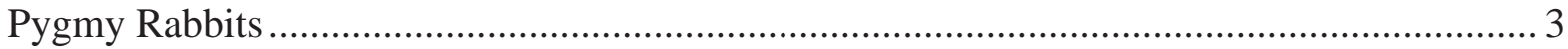

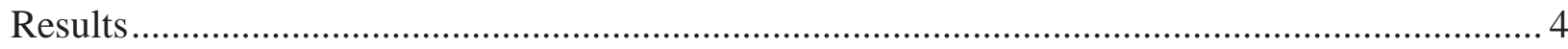

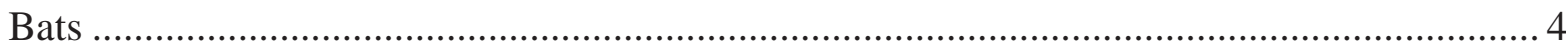

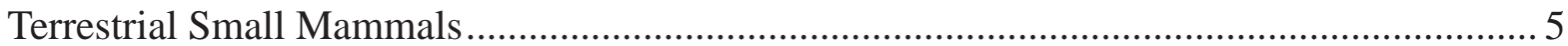

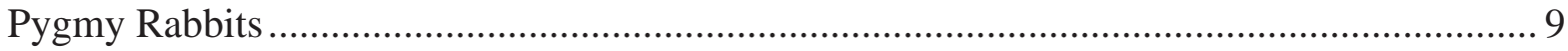

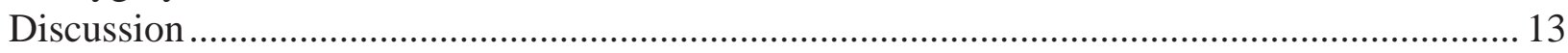

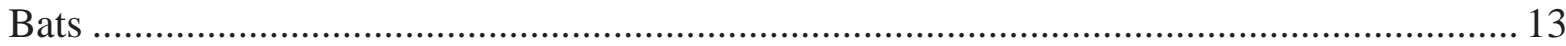

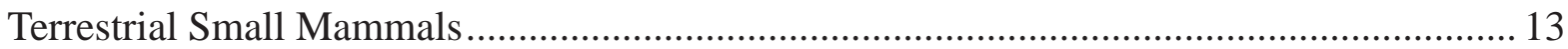

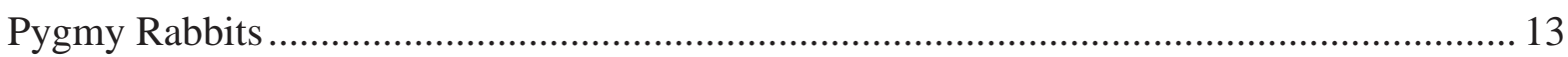

Recommendations ........................................................................................................ 14

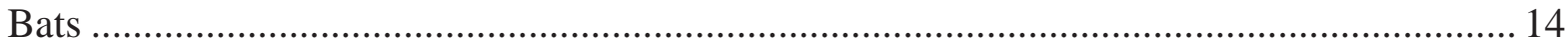

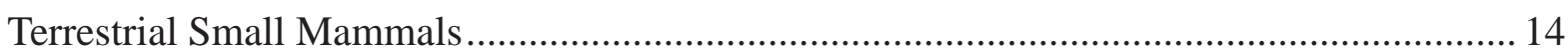

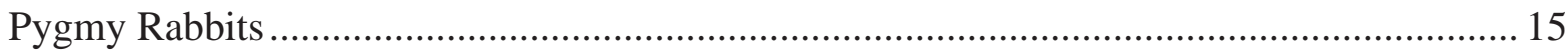

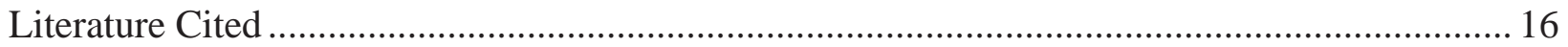

\section{List OF Figures}

Figure 1. Acoustic monitoring station for bat vocalization capture including Pettersson detector and MP3 player ................................................................... 2

Figure 2. Pitfall traps with drift fences ................................................................................. 3

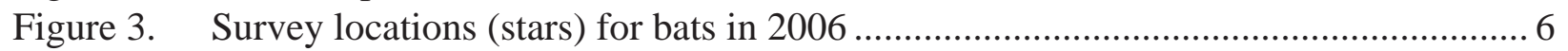

Figure 4. Survey locations for terrestrial small mammals in 2006 ............................................ 7

Figure 5. Survey locations for Pygmy Rabbits in southwestern Montana during

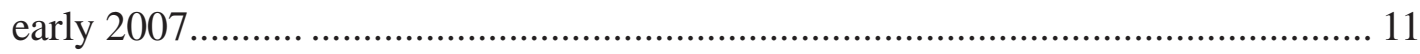

Figure 6. Pygmy Rabbit at an entrance to its burrow system in the Grasshopper Creek site (Site 3) ................................................................................................ 12

Figure 7. Sign of Pygmy Rabbit activity at Grasshopper Creek ................................................ 12

\section{List OF TABLES}

Table 1. Bats detected at various sites across Montana during surveys in 2006 ......................... 4

Table 2. Small mammals captured during 2006 at several sites in central and

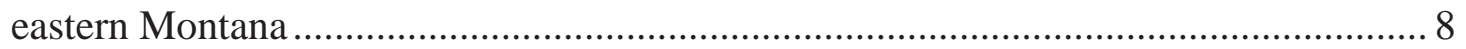

Table 3. Survey sites for Pygmy Rabbits in late winter 2007 ...................................................... 9 


\section{INTRODUCTION}

The lack of good inventory and distribution data has been a major impediment in recent status reviews for several species of small mammals in Montana. The U.S. Bureau of Land Management (BLM) lists several of these species in the state as Sensitive Species, including seven bats (Pallid Bat Antrozous pallidus; Townsend's Big-eared Bat Corynorhinus townsendii; Spotted Bat Euderma maculatum; Western Long-eared Myotis Myotis evotis; Northern Myotis M. septentrionalis; Fringed Myotis M. thysanodes; Long-legged Myotis M. volans) and one lagomorph (Pygmy Rabbit Brachylagus idahoensis). Other species formerly listed as BLM Sensitive (e.g. Merriam's Shrew Sorex merriami; Dwarf Shrew S. nanus; Preble's Shrew S. preblei; Hispid Pocket Mouse Chaetodipus hispidus) were dropped due to insufficient data with which to assess habitat requirements and rarity or threatened status.

Significant gaps in our knowledge of the distribution and habitat requirements of these species make it difficult for managers to assess threats and implement conservation and management actions to safeguard their populations and habitats. New inventories are needed to fill gaps in known distributions and to develop baseline information in advance of anticipated disturbances, particularly in resource extraction areas. New information will also aid in identifying priorities among species and sites for conservation and management activities.

Habitat information is also lacking for many of the Sensitive small mammal species. Because terrestrial small mammals have limited distributions and small home ranges, they are susceptible to population declines resulting from habitat degradation at many scales, including local disturbances. However, detailed data concerning specific habitat influences on abundance and distribution are lacking, and this limits the ability of managers to effectively sustain healthy populations across the landscape.

Distribution and status of bats also remain poorly documented across Montana landscapes. A summary of all existing bat records from the region clearly shows large distribution gaps for all species, further underscoring the need for additional surveys. Even though bats are more mobile than other small mammals, with larger home ranges and the ability to make long-distance movements in a relatively short time, the gaps in their documented distributions is of conservation interest because management activities on landscapes may have unintended negative consequences on the localized habitats bats depend upon for roosting and foraging.

The ultimate goal of a sensitive species program is to maintain or ensure recovery of those at-risk species, and to proactively provide information on declining species so they may be effectively managed before they decline to the point of listing. The Montana Department of Fish, Wildlife and Parks (MTFWP) recently completed an initial inventory of small mammals on state lands (Carson et al. 2006). The project we describe in this report was designed to compliment the MTFWP effort, by focusing on BLM and nearby lands, to build an accurate portrait of the distribution and status of small mammals in Montana. 


\section{Methods}

Montana Natural Heritage Program (MTNHP) databases were reviewed to evaluate where data gaps existed in the distributions of small mammals, both in geographic areas and for particular species. From this review, we identified priority areas for sampling. For bats, these included southwestern Beaverhead County, central Montana adjacent to the Missouri and Musselshell rivers, and southeastern Montana. Bat surveys were conducted in late June, August, and early September 2006. We limited our terrestrial small mammal trapping mostly to central Montana, because of time and other logistical constraints, and there our focus was sagebrush habitat. Trapping occurred in late August and September 2006. We also devoted a limited amount of time to surveys for Pygmy Rabbits in late February and early March 2007, primarily fleshing out their distribution in sagebrush habitat surrounding the Pioneer Mountains in Beaverhead County.

All survey site locations were recorded on GPS units; capture/detection data was recorded in the field on standardized data sheets or in field notebooks, and later transcribed to a Point Observation Database (POD) housed at the Montana Natural Heritage Program, Helena, where it is available for agency and public use.

\section{Bats}

Acoustic sampling is an important component of inventory and monitoring efforts (see Hayes 1997 and O'Farrell and Gannon 1999 for examples), and was the primary survey method we used during this project. The survey protocol we followed called for acoustic monitoring at each site using a Pettersson 240x detector. Vocalizations were downloaded in the field directly to a laptop computer, or to a 1GB iRiver MP3 player left in place overnight, and later converted and stored on a laptop (Figure 1). Vocalizations were analyzed using SonoBat ${ }^{\circledR}$ software (version 2.5; DNDesign); vocalizations were identified based on congruence with reference calls and descriptions of call structure (Swezick, personal communication). Vocalization data were used only for species

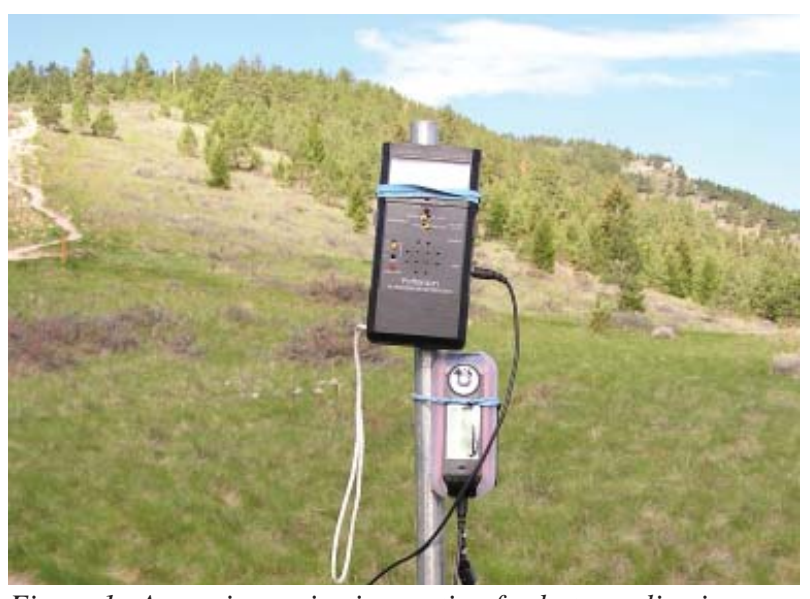

Figure 1. Acoustic monitoring station for bat vocalization capture including Pettersson detector and MP3 player.

determinations, not inferences about relative abundance.

Bats were also captured at a few sites using mist nets of various lengths and configurations; number of nets deployed varied among sites. Nets were deployed at twilight and left open up to 3 hours, weather permitting, or until at least 1 hour passed without acoustic detections. Species identification was based on published keys and species accounts (van Zyll de Jong 1985, Nagorsen and Brigham 1993, Adams 2003). Standard measurements (weight, forearm length, ear length, sex, age, reproductive status) were obtained from each individual. Wing punch tissue samples were also collected from captured bats. Tissue was taken using sterile procedures and stored in biopsy tubes containing $95 \%$ ethanol. Tissue is to be used for genetic identification of species pairs difficult to distinguish in the field (especially Myotis lucifugus and M. yumanensis); genetic analysis has not been completed at the time of this report.

\section{Terrestrial Small Mammals}

Trapping of small terrestrial mammals involved use of a combination of trap lines and pitfall trap arrays. Sherman live traps and museum special snap traps were set at each station on trap lines, with ten stations per trap line spaced approximately $10 \mathrm{~m}$ apart. Live traps were baited with rolled oats and commercial birdseed. A piece of quilt batting 
was placed in each live trap as protection against the possibility of hypothermia. Snap traps were baited with peanut butter. Pitfall arrays consisted of a central pit with three 8-foot long masonite drift fences radiating from the central pit equidistant from each other. Each drift fence terminated at another pit. Thus, each array consisted of four pits at either end of three drift fences. Pits were $9 \mathrm{~cm}$ diameter plastic drinking cups sunk into the ground with the lip at ground level, and half filled with non-toxic antifreeze. Pit cups were nested into a second cup to allow removal of the pit cup without the pit collapsing (Figure 2).

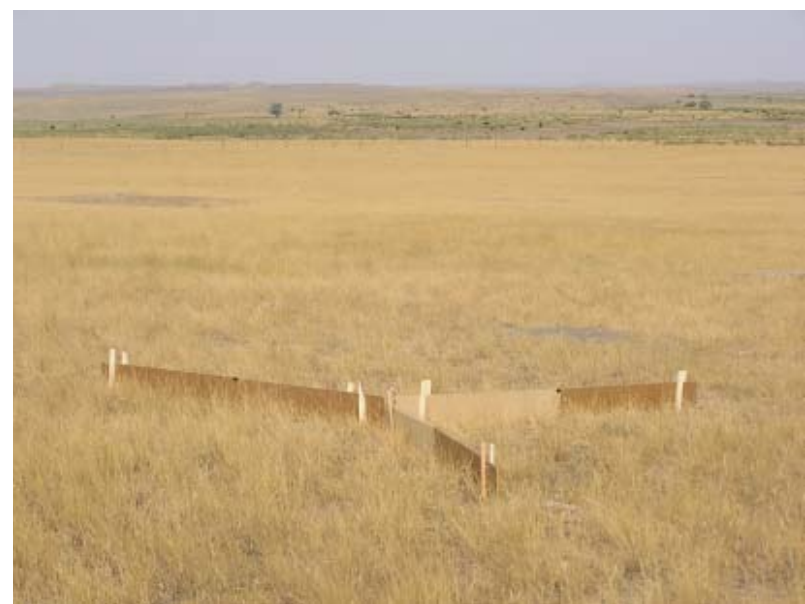

Figure 2. Pitfall traps with drift fences.

Depending on the size of the habitat patch to be sampled, we set from one to three trap lines (usually three) and two pitfall arrays prior to sunset at each site; trap lines were run for two consecutive nights (three nights at sites SS13 and SS14 in Petroleum County). Traps were left closed during the day after being checked early in the morning. Pitfall arrays were left open for the duration of the trapping session, night and day, and checked each morning concurrent with trap-line checks. Animals captured were identified to species, sex, and age, and reproductive status was determined when possible.

\section{Pygmy Rabbits}

Sites for surveys were selected from coarse-scale maps of sagebrush cover intersecting BLM lands in areas with either no prior surveys or documented recent Pygmy Rabbit activity. Once an area was chosen for survey, we scanned the general site for denser stands of sagebrush, and then walked through the stands in a manner covering the greatest amount of ground in the least amount of time. Multiple observers (most often three persons) conducted the site surveys, thereby increasing the probability of intersecting Pygmy Rabbit tracks or burrow systems. At each site, the overall search involved walking a loop path through the area to maximize the amount of ground covered without surveying the same ground twice. If present on the site, denser sagebrush clumps were specifically targeted for survey. Tracks, when present, were followed to locate burrows. Using these methods, the survey routes were not random, straight, or well-defined, but followed the general protocols recommended for Pygmy Rabbit surveys (Roberts 2001, Ulmschneider 2003). We successfully used this same protocol during earlier Pygmy Rabbit surveys in Montana (Lenard et al. 2005).

Pygmy Rabbit activity was confirmed by the presence of burrows, droppings, sagebrush floret clippings, tracks, and direct observation of individual rabbits. At burrow systems we recorded the number and GPS location of openings, an estimate of the areal extent of the system, the presence of fresh pellets, clippings, urine stains, and/or any visual encounters with rabbits. 


\section{Results}

\section{Bats}

We sampled 18 sites in six counties for bats, from Beaverhead County in the southwest to Carter County in the southeast (Figure 3), with the majority of sites clustered in central Montana. We conducted acoustic sampling with bat detectors at all sites, whereas mist nets were used at only three sites (in Beaverhead County). Bats were definitively identified to species at 17 sites (Table 1). Calls were collected at one additional site in Garfield County (T21NR35E, Sec. 35) surveyed on 9 September 2006, but no definitive identifications were possible from the calls.

We identified eight species of bats through recorded vocalization and capture during our surveys, representing 53\% of the 15 bat species known to occur in Montana (Foresman 2001, Hendricks et al. 2006). Three of the bat species we identified during our 2006 surveys are BLM state Sensitive Species. These include Western Longeared Myotis, Fringed Myotis, and Long-legged Myotis. All species were identified through calls, and five of these species were also identified inhand during netting in Beaverhead County. No bat species was definitively identified at all sites. Big Brown Bat (Eptesicus fuscus) was identified at two sites (Table 1), Hoary Bat (Lasiurus cinereus) at 12 sites, Silver-haired Bat (Lasionycteris noctivagans) at six sites, Western Small-footed Myotis (Myotis ciliolabrum) at seven sites, Western Long-eared Myotis (M. evotis) at seven sites, Little Brown Myotis (M. lucifugus) at 11 sites, Fringed Myotis (M. thysanodes) at three sites, and Long-legged Myotis (M. volans) at seven sites. Among the seven individual bats captured at two sites in Beaverhead County was a pregnant female Longlegged Myotis at Keystone Reservoir on 26 June.

We added six first county records for the three BLM Sensitive Species identified during our 2006 surveys: Western Long-eared Myotis (Petroleum), Fringed Myotis (Beaverhead, Garfield, Petroleum), and Long-legged Myotis (Garfield, Petroleum). Additional first county records from our surveys included Big Brown Bat (Petroleum), Hoary Bat (Garfield), Silver-haired Bat (Garfield, Petroleum), Western Small-footed Myotis (Petroleum), and Little Brown Myotis (Garfield, Petroleum). In summary, we documented one first county record for Beaverhead County (Fringed Myotis), five first county records for Garfield County (Hoary Bat, Silver-haired Bat, Little Brown Myotis, Fringed Myotis, Long-legged Myotis), and seven first county records for Petroleum County (Big Brown Bat, Silver-haired Bat, Western Small-footed Myotis, Western Long-eared Myotis, Little Brown Myotis, Fringed Myotis, Long-legged Myotis).

Table 1. Bats detected at various sites across Montana during surveys in 2006. Site numbers correspond to Figure 3. An asterisk (*) indicates the species was captured; all other detections are based on recorded call characteristics.

\begin{tabular}{|l|l|l|l|l|}
\hline \multicolumn{1}{|c|}{ County } & \multicolumn{1}{c|}{ Site } & \multicolumn{1}{c|}{ Location } & \multicolumn{1}{c|}{ Date } & \multicolumn{1}{c|}{ Species $^{\text {a }}$} \\
\hline 1. Beaverhead & Big Sheep Creek & T13SR10W, Sec 36 & 25 Jun & MYLU \\
\hline 2. Beaverhead & Caboose Canyon & T14SR10W, Sec 22 & 24 Jun & $\begin{array}{l}\text { LACI, MYLU, } \\
\text { MYTH }\end{array}$ \\
\hline 3. Beaverhead & Deadman Creek & T15SR10W, Sec 10 & 23 Jun & EPFU*, MYLU* \\
\hline 4. Beaverhead & Keystone Reservoir & T11SR12W, Sec 35 & 26 Jun & $\begin{array}{l}\text { LACI*, MYCI, } \\
\text { MYEV*, MYVO* }\end{array}$ \\
\hline 5. Carter & Dry Creek Road & T1SR55E, Sec 8 & 14-15 Sep & LACI, MYLU \\
\hline 6. Fergus & $\begin{array}{l}\text { Woodhawk } \\
\text { Campground }\end{array}$ & T23NR21E, Sec 21 & 6 Sep & $\begin{array}{l}\text { LACI, MYCI, } \\
\text { MYVO }\end{array}$ \\
\hline
\end{tabular}


Table 1. Continued.

\begin{tabular}{|l|l|l|l|l|}
\hline \multicolumn{1}{|c|}{ County } & \multicolumn{1}{|c|}{ Site } & \multicolumn{1}{c|}{ Location } & \multicolumn{1}{c|}{ Date } & \multicolumn{1}{c|}{ Species } \\
\hline 7. Fergus & Woodhawk Creek & T23NR22E, Sec 19 & 7 Sep & $\begin{array}{l}\text { LACI, LANO, } \\
\text { MYEV, MYLU }\end{array}$ \\
\hline 8. Garfield & 7-W Ranch & T19NR31E, Sec 8 & 24-25 Aug & $\begin{array}{l}\text { LACI, LANO, } \\
\text { MYCI, MYLU }\end{array}$ \\
\hline 9. Garfield & Rattlesnake Flat & T21NR40E, Sec 5 & 8 Sep & $\begin{array}{l}\text { LACI, MYCI, } \\
\text { MYLU, MYTH, } \\
\text { MYVO }\end{array}$ \\
\hline 10. Petroleum & $\begin{array}{l}\text { War Horse } \\
\text { Reservoir }\end{array}$ & T16NR25E, Sec 30 & 14 Aug & $\begin{array}{l}\text { LACI, MYEV, } \\
\text { MYLU, MYTH, } \\
\text { MYVO }\end{array}$ \\
\hline 11. Petroleum & $\begin{array}{l}\text { Yellow Water } \\
\text { Reservoir }\end{array}$ & T13NR26E, Sec 7 & 22 Aug & $\begin{array}{l}\text { EPFU, LACI, } \\
\text { MYEV, MYLU }\end{array}$ \\
\hline 12. Petroleum & Petrolia Lake & T14NR27E, Sec 25 & 23 Aug & $\begin{array}{l}\text { LACI, LANO, } \\
\text { MYLU }\end{array}$ \\
\hline 13. Petroleum & 79 Trail & T18NR28E, Sec 13 & 11 Sep & MYCI \\
\hline 14. Petroleum & Horse Camp Trail & T20NR27E, Sec 22 & 8 Sep & $\begin{array}{l}\text { LACI, LANO, } \\
\text { MYVO }\end{array}$ \\
\hline 15. Petroleum & $\begin{array}{l}\text { Horse Camp } \\
\text { Reservoir }\end{array}$ & T20NR27E, Sec 26 & 9 Sep & $\begin{array}{l}\text { LACI, LANO, } \\
\text { MYCI, MYEV, } \\
\text { MYLU, MYVO }\end{array}$ \\
\hline 16. Phillips & CK Ridge & T22NR27E, Sec 11 & 10 Sep & LANO, MYEV \\
\hline 17. Phillips & Dan Reservoir & T22NR27E, Sec 2 & 11 Sep & $\begin{array}{l}\text { MYCI, MYEV, } \\
\text { MYVO }\end{array}$ \\
\hline
\end{tabular}

a Species codes: EPFU (Eptesicus fuscus, Big Brown Bat), LACI (Lasiurus cinereus, Hoary Bat), LANO (Lasionycteris noctivagans, Silver-haired Bat), MYCI (Myotis ciliolabrum, Western Small-footed Myotis), MYEV (Myotis evotis, Western Long-eared Myotis), MYLU (Myotis lucifugus, Little Brown Myotis), MYTH (Myotis thysanodes, Fringed Myotis), MYVO (Myotis volans, Long-legged Myotis).

\section{Terrestrial Small Mammals}

We trapped terrestrial small mammals at 22 sites in eastern Montana (Figure 4) during late summer 2006. In 2320 trap-nights of trap line exposure we captured 409 individuals of six rodent species: Ord's Kangaroo Rat (Dipodomys ordii), Sagebrush Vole (Lemmiscus curtatus), Olive-backed Pocket Mouse (Perognathus fasciatus), Deer Mouse (Peromyscus maniculatus), Western Harvest Mouse (Reithrodontomys megalotis), and Northern Pocket Gopher (Thomomys talpoides). None of these is a BLM Sensitive Species in Montana. One species, the Deer Mouse, represented 96.3\% of our total captures (Table 2). The other five species were represented by six or fewer captures each. Only one individual mammal (a juvenile Sagebrush
Vole) was captured in a pitfall trap during 84 arraynights of exposure, although we caught ten Tiger Salamanders (Ambystoma tigrinum) in pitfall traps at sites SS13 and SS14 following evening rains. We captured no shrews.

Sites where we trapped had average sagebrush cover along trap lines of $0.0 \%$ to $37.4 \%$ (Table 2). Nevertheless, the Deer Mouse was captured at every site. Only two other species, Sagebrush Vole and Olive-backed Pocket Mouse, were captured at more than one site. The Olive-backed Pocket Mouse (three sites) appeared to occupy sites with sagebrush cover on the lower end of the range (12.6\% or less), whereas Sagebrush Vole (four sites) was present at sites across virtually the 


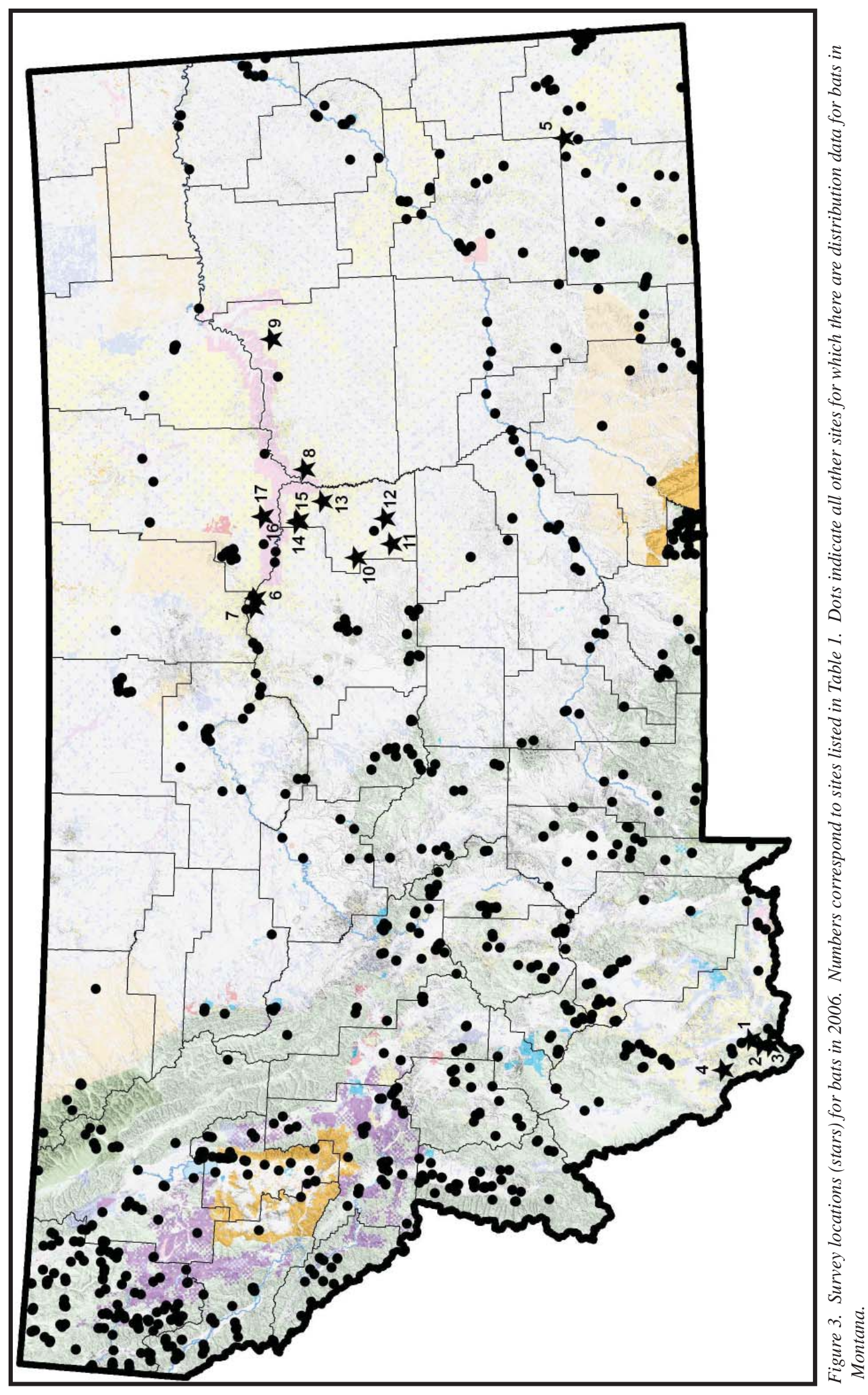




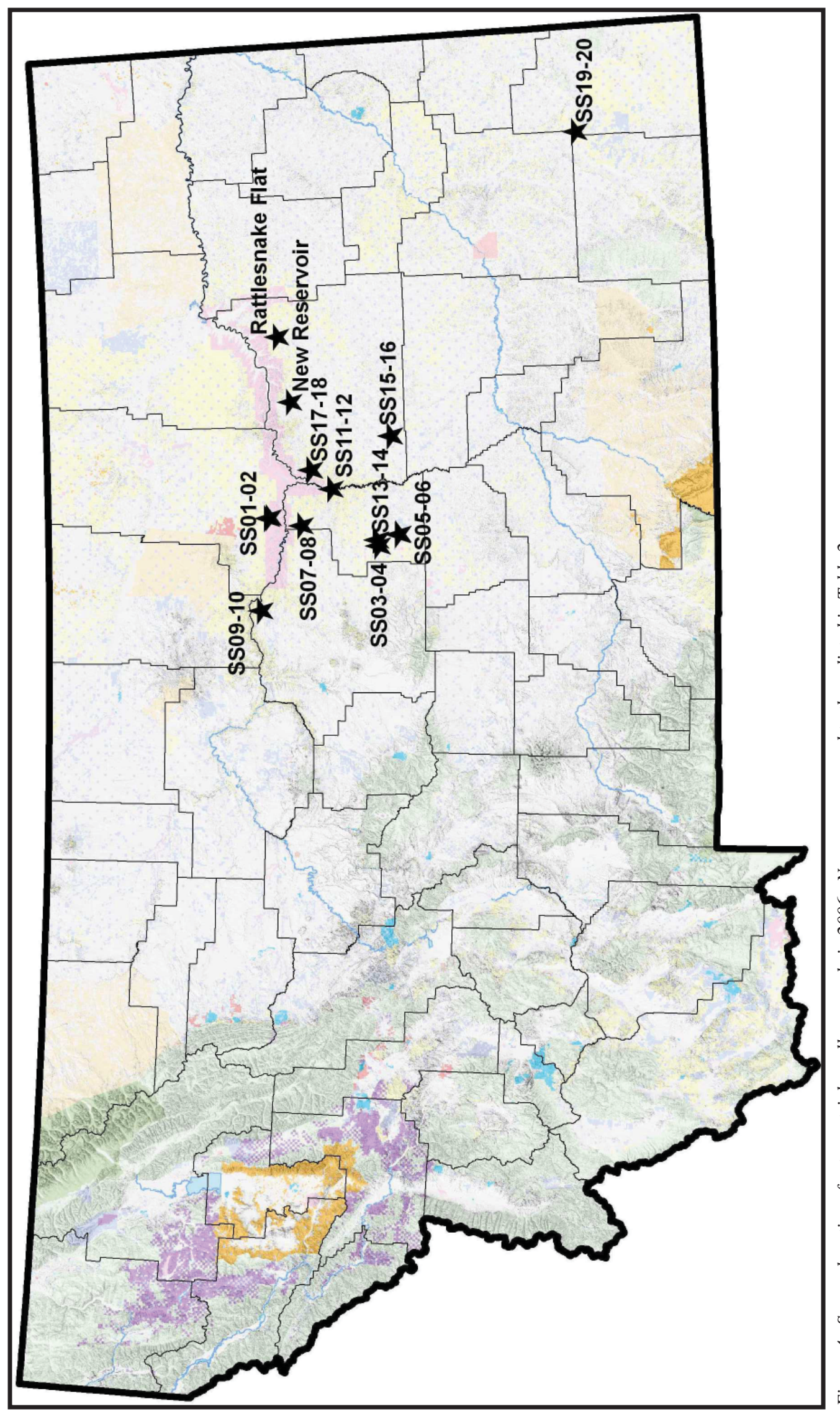

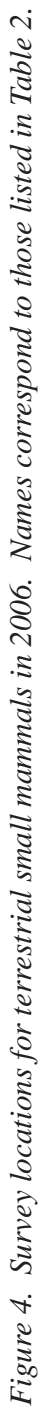


Table 2. Small mammals captured during 2006 at several sites in central and eastern Montana. Site names correspond to Figure 4. Numbers captured for each species are in parentheses.

\begin{tabular}{|c|c|c|c|c|c|}
\hline County & Site & Location & Date & $\begin{array}{l}\text { Sagebrush } \\
\text { Cover (\%) }\end{array}$ & Species $^{a}$ \\
\hline Phillips & SS01 & T22NR27E, Sec 12 & 11-12 Sep & 1.8 & PEMA (18) \\
\hline Phillips & SS02 & T23NR27E, Sec 35 & 11-12 Sep & 13.9 & PEMA (21) \\
\hline Petroleum & SS03 & T15NR26E, Sec 30 & 24-25 Aug & 36.0 & $\begin{array}{l}\text { PEMA (44), } \\
\text { LECU (1) }\end{array}$ \\
\hline Petroleum & SS04 & T15NR26E, Sec 30 & 24-25 Aug & 1.9 & PEMA (5) \\
\hline Petroleum & SS05 & T13NR26E, Sec 12 & 23-24 Aug & 22.0 & PEMA (7) \\
\hline Petroleum & SS06 & T13NR26E, Sec 1 & 23-24 Aug & 0.0 & PEMA (9) \\
\hline Petroleum & SS07 & T20NR27E, Sec 16 & 9-10 Sep & 7.7 & $\begin{array}{l}\text { PEMA (57), } \\
\text { PEFA (2) }\end{array}$ \\
\hline Petroleum & SS08 & T20NR27E, Sec 16 & 9-10 Sep & 0.0 & $\begin{array}{l}\text { PEMA (61), } \\
\text { THTA (1) }\end{array}$ \\
\hline Fergus & SS09 & T23NR21E, Sec 28 & 7-8 Sep & 27.8 & PEMA (4) \\
\hline Fergus & SS10 & T23NR21E, Sec 28 & 7-8 Sep & 0.0 & PEMA (2) \\
\hline Petroleum & SS11 & T18NR29E, Sec 24 & 11-12 Sep & 37.4 & PEMA (34) \\
\hline Petroleum & SS12 & T18NR29E, Sec 24 & 11-12 Sep & 0.0 & $\begin{array}{l}\text { PEMA (9), } \\
\text { PEFA (1), } \\
\text { DIOR (3) }\end{array}$ \\
\hline Petroleum & SS13 & T15NR26E, Sec 22 & 15-17 Aug & 24.5 & PEMA (11) \\
\hline Petroleum & SS14 & T15NR26E, Sec 22 & 15-17 Aug & 2.1 & $\begin{array}{l}\text { PEMA (16), } \\
\text { LECU (2) }\end{array}$ \\
\hline Garfield & SS15 & T14NR33E, Sec 26 & 7-8 Sep & 37.2 & $\begin{array}{l}\text { PEMA (14), } \\
\text { LECU (1) }\end{array}$ \\
\hline Garfield & SS16 & T14NR33E, Sec 26 & 7-8 Sep & 2.6 & $\begin{array}{l}\text { PEMA (9), } \\
\text { LECU (1) }\end{array}$ \\
\hline Garfield & SS17 & T19NR31E, Sec 8 & 25-26 Aug & 2.1 & PEMA (12) \\
\hline Garfield & SS18 & T19NR31E, Sec 8 & 25-26 Aug & 12.6 & $\begin{array}{l}\text { PEMA (18), } \\
\text { PEFA (1) }\end{array}$ \\
\hline Carter & SS19 & T1SR55E, Sec 8 & 15-16 Sep & 16.5 & PEMA (14) \\
\hline Carter & SS20 & T1SR55E, Sec 8 & 15-16 Sep & 0.4 & PEMA (10) \\
\hline Garfield & Rattlesnake Flat & T21NR40E, Sec 5 & 9 Sep & --- & $\begin{array}{l}\text { PEMA (4), } \\
\text { REME (1) }\end{array}$ \\
\hline Garfield & New Reservoir & T21NR35E, Sec 35 & 10 Sep & --- & PEMA (16) \\
\hline
\end{tabular}

a Species codes: DIOR (Dipodomys ordii, Ord's Kangaroo Rat), LECU (Lemmiscus curtatus, Sagebrush Vole), PEFA (Perognathus fasciatus, Olive-backed Pocket Mouse), PEMA (Peromyscus maniculatus, Deer Mouse), REME (Reithrodontomys megalotis, Western Harvest Mouse), THTA (Thomomys talpoides, Northern Pocket Gopher). 
full spectrum of sagebrush cover. It is perhaps noteworthy that Ord's Kangaroo Rat was captured at only one site, but this was where there was no sagebrush cover along the trap lines. In addition, trap lines at three sites of old burns or little sagebrush cover (SS06, SS17, and SS18) were adjacent to, or intersected, colonies of Black-tailed Prairie Dog (Cynomys ludoviscianus).

None of our captures represented first county records, but several helped fill distribution gaps. The Northern Pocket Gopher capture is only the third reported for this species from Petroleum County. The three records of Olive-backed Pocket Mouse fill gaps along either side of the Musselshell River in Petroleum and Garfield counties, and include the third and fourth locations of the species for Petroleum County. The Sagebrush Vole captures include the third and fourth locations (and southern-most) reported for Garfield County. And the Western Harvest Mouse capture is only the second reported location for Garfield County.

\section{Pygmy Rabbits}

We reviewed 24 sites in late February-early March 2007 for Pygmy Rabbit activity. Twenty-one survey sites were on BLM lands, the remaining three on State lands. Our on-ground survey effort was aided by the presence of snow cover, which made finding Pygmy Rabbits much easier, as fresh tracks are indication of activity and can be followed to burrow systems. Four sites were found to have current Pygmy Rabbit activity (Figure 5, Table 3); fresh tracks and active burrows were present at all sites classified as active. There was no evidence of Pygmy Rabbit activity at twelve sites, eight sites were considered to be inappropriate habitat (no sagebrush present, or the presence of dense conifers on the site), and two sites were considered to have potential habitat but were inaccessible for survey due to deep snow. While surveys of the majority of sites revealed no evidence of Pygmy Rabbit activity, those with activity provided ample evidence of the presence of Pygmy Rabbits, with fresh tracks, pellets, urine stains, burrow holes, fresh sagebrush clippings, and the rare visual encounter of a Pygmy Rabbit. Summaries for the active sites (see Table 3) follow.

Site 1. South of Toomey Lake, T1N R14W Sec. 26 (Deer Lodge County); BLM section.

Tracks were evident in the snow at this site in the Big Hole Valley, and covered an area of

Table 3. Survey sites for Pygmy Rabbits in late winter 2007. Site numbers correspond to Figure 5.

\begin{tabular}{|l|c|l|c|c|c|}
\hline \multicolumn{1}{|c|}{ Site } & Date & \multicolumn{1}{|c|}{ Evidence } & Township & Range & Section \\
\hline $\begin{array}{l}\text { 1. Toomey Lake SW } \\
\text { - BLM }\end{array}$ & $28 \mathrm{Feb}$ & Active burrow system & $1 \mathrm{~N}$ & $14 \mathrm{~W}$ & $26 \mathrm{NW}$ \\
\hline $\begin{array}{l}\text { 2. Patterson Springs } \\
\text { South - BLM }\end{array}$ & $28 \mathrm{Feb}$ & Active burrow system & $5 \mathrm{~S}$ & $14 \mathrm{~W}$ & $31 \mathrm{SW}$ \\
\hline $\begin{array}{l}\text { 3. Grasshopper } \\
\text { Creek East - BLM }\end{array}$ & $1 \mathrm{Mar}$ & Active burrow system & $6 \mathrm{~S}$ & $12 \mathrm{~W}$ & $\begin{array}{c}29 \mathrm{NW} / \\
30 \mathrm{NE}\end{array}$ \\
\hline $\begin{array}{l}\text { 4. E of Steel Creek } \\
\text { (NE of Wisdom) - } \\
\text { State }\end{array}$ & $1 \mathrm{Mar}$ & Active burrow system & $2 \mathrm{~S}$ & $15 \mathrm{~W}$ & $\begin{array}{c}34 \mathrm{NE} / \\
35 \mathrm{NW}\end{array}$ \\
\hline $\begin{array}{l}\text { 5. Browne's Bridge } \\
\text { / Big Hole River - } \\
\text { BLM }\end{array}$ & $26 \mathrm{Feb}$ & No evidence of PR activity & $3 \mathrm{~S}$ & $9 \mathrm{~W}$ & $27 \mathrm{NE}$ \\
\hline $\begin{array}{l}\text { 6. Buhrer School } \\
\text { Site - BLM }\end{array}$ & $27 \mathrm{Feb}$ & No evidence of PR activity & $4 \mathrm{~S}$ & $8 \mathrm{~W}$ & $19 \mathrm{~S}$ \\
\hline $\begin{array}{l}\text { 7. Canyon Creek } \\
\text { Road - BLM }\end{array}$ & $26 \mathrm{Feb}$ & No evidence of PR activity & $2 \mathrm{~S}$ & $10 \mathrm{~W}$ & $24 \mathrm{NW}$ \\
\hline
\end{tabular}


Table 3. Continued.

\begin{tabular}{|c|c|c|c|c|c|}
\hline Site & Date & Evidence & Township & Range & Section \\
\hline $\begin{array}{l}\text { 8. Cherry Creek } \\
\text { Road - BLM }\end{array}$ & 26 Feb & No evidence of PR activity & $3 S$ & $9 \mathrm{~W}$ & $5 \mathrm{SE}$ \\
\hline $\begin{array}{l}\text { 9. Dry Hollow } \\
\text { Gulch - BLM }\end{array}$ & 26 Feb & No evidence of PR activity & $2 \mathrm{~S}$ & $9 \mathrm{~W}$ & $\begin{array}{l}28 \mathrm{NW} / \\
29 \mathrm{NE}\end{array}$ \\
\hline $\begin{array}{l}\text { 10. Greenstone Gulch } \\
\text { - BLM }\end{array}$ & 27 Feb & No evidence of PR activity & $5 S$ & $9 \mathrm{~W}$ & $\begin{array}{l}\text { 18NE / } \\
7 \mathrm{SE}\end{array}$ \\
\hline $\begin{array}{l}\text { 11. Jerry Creek - } \\
\text { State }\end{array}$ & 28 Feb & No evidence of PR activity & $1 \mathrm{~N}$ & $11 \mathrm{~W}$ & 36SE \\
\hline $\begin{array}{l}\text { 12-13. Moose Creek } \\
\text { Area - BLM }\end{array}$ & 2 Mar & No evidence of PR activity & $1 \mathrm{~S}$ & $9 \mathrm{~W}$ & $\begin{array}{l}27 \mathrm{~S} / \\
34 \mathrm{SE}\end{array}$ \\
\hline $\begin{array}{l}\text { 14. Nez Perce Creek } \\
\text { - BLM }\end{array}$ & 27 Feb & No evidence of PR activity & $4 \mathrm{~S}$ & $7 \mathrm{~W}$ & 4 \\
\hline $\begin{array}{l}\text { 15. Swamp Creek } \\
\text { - BLM }\end{array}$ & 28 Feb & No evidence of PR activity & $3 S$ & $16 \mathrm{~W}$ & 3NENE \\
\hline $\begin{array}{l}\text { 16. Bear Creek - } \\
\text { BLM }\end{array}$ & $1 \mathrm{Mar}$ & Not appropriate habitat & $2 \mathrm{~N}$ & $12 \mathrm{~W}$ & $34 S$ \\
\hline $\begin{array}{l}\text { 17. Dickey Bridge } \\
\text { - BLM }\end{array}$ & $1 \mathrm{Mar}$ & Not appropriate habitat & $1 \mathrm{~N}$ & $12 \mathrm{~W}$ & $14 S W$ \\
\hline $\begin{array}{l}\text { 18-19. Camp Creek } \\
\text { Area - BLM }\end{array}$ & $2 \mathrm{Mar}$ & Not appropriate habitat & $2 \mathrm{~S}$ & $9 \mathrm{~W}$ & $\begin{array}{c}18 S \text { / } 19 \text { / } \\
24 S W\end{array}$ \\
\hline $\begin{array}{l}\text { 20. Quartz Hill } \\
\text { Gulch - BLM }\end{array}$ & 28 Feb & Not appropriate habitat & $1 \mathrm{~S}$ & $10 \mathrm{~W}$ & $\begin{array}{l}5 \mathrm{SE} / \\
8 \mathrm{SE}\end{array}$ \\
\hline $\begin{array}{l}\text { 21. South Fork } \\
\text { Divide Creek - BLM }\end{array}$ & 2 Mar & Not appropriate habitat & $1 \mathrm{~N}$ & $9 \mathrm{~W}$ & $4 \mathrm{SW}$ \\
\hline $\begin{array}{l}\text { 22. Sportsman Park } \\
\text { - State }\end{array}$ & 28 Feb & Not appropriate habitat & $2 \mathrm{~N}$ & $13 W$ & 36 \\
\hline $\begin{array}{l}\text { 23. Indian Creek - } \\
\text { BLM }\end{array}$ & 27 Feb & Inaccessible & $4 \mathrm{~S}$ & $4 \mathrm{~W}$ & $18 \mathrm{NE}$ \\
\hline $\begin{array}{l}\text { 24. Wise River Area, } \\
\text { W of airport - BLM }\end{array}$ & $1 \mathrm{Mar}$ & $\begin{array}{l}\text { Inaccessible - potential } \\
\text { habitat }\end{array}$ & $1 \mathrm{~S}$ & $11 \mathrm{~W}$ & $5 S / 7$ \\
\hline
\end{tabular}

approximately 20 x $20 \mathrm{~m}$. Thirteen open holes in one burrow system were discovered. No individual rabbits were observed, but fresh tracks, pellets, and sagebrush floret clippings indicated current activity. This area was documented by Ryan Rauscher in May 1997 as having an active burrow system.

Site 2. Patterson Springs South, T5S R14W Sec. 31 (Beaverhead County); BLM parcel (formerly
USFS). We found four active burrow systems at this location in the Big Hole Valley; two with 8 holes, one with 7 holes, and an additional system with 10 holes. Fresh tracks, pellets, sagebrush floret clippings, and urine stains were evident at this site. This site was also documented by Ryan Rauscher in May 1997 as having an active burrow system. 


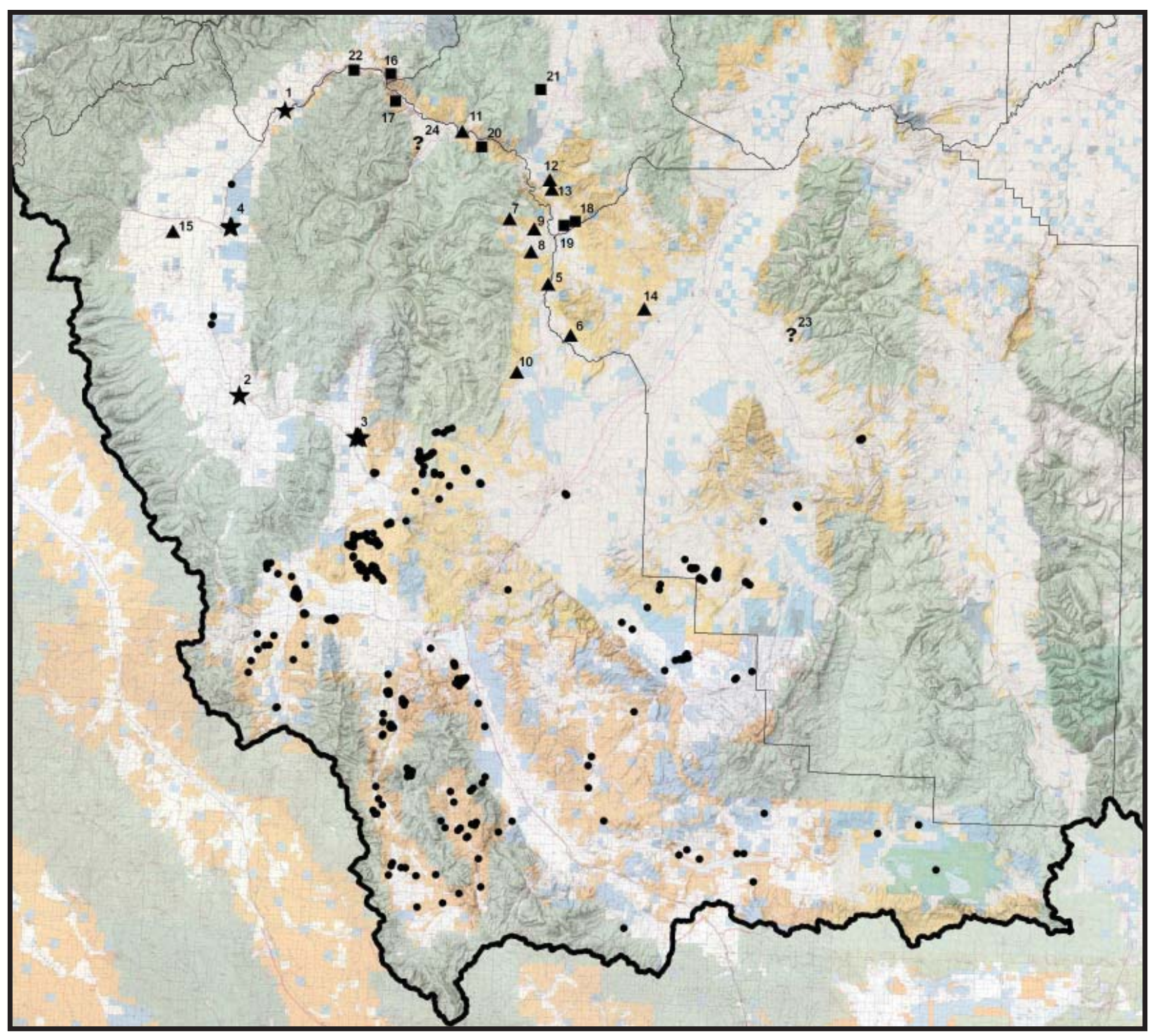

Figure 5. Survey locations for Pygmy Rabbits in southwestern Montana during early 2007. Stars are active sites, triangles are potential habitat with no evidence of Pygmy rabbits, squares are sites with inappropriate habitat, and question mark designates sites of potential habitat that were inaccessible at the time of our survey. Numbers correspond to sites listed in Table 3. Dots represent prior locations with evidence of Pygmy Rabbit activity.

Site 3. Grasshopper Creek East, T6S R12W Sec. 29 and 30 (Beaverhead County); BLM sections. We found multiple burrow systems at this site in the Grasshopper Valley, a location previously undocumented for Pygmy Rabbit activity. Survey of this area included over $1 \mathrm{~km}$ of linear distance, and included observation of 13 burrow systems. Some systems were connected by tracks, yet appeared to be spatially isolated and distinct from other burrow systems. Two burrow systems consisted of a single hole each, five systems were of 2 holes, two of 3 holes, two 4 holes each, one of 6 holes, and another with 13 holes. We confirmed activity at this site with fresh tracks, pellets, urine stains, sagebrush floret clippings, and visual encounter of two individual Pygmy Rabbits by two different observers (see Figures 6 and 7).

Site 4. East of Steel Creek, northeast of Wisdom, T2S R15W, Sec. 34 and 35 (Beaverhead County); State sections. We found four burrow systems at this site in the Big Hole Valley, a location previously undocumented for Pygmy Rabbit activity. One burrow system had 11 holes, and was approximately $500 \mathrm{~m}$ from another system with 14 holes. Two other burrow systems were located 
approximately $250 \mathrm{~m}$ from the 14-hole system, and were comprised of 3 holes each. Activity between these last two burrow systems was evident by tracks of at least two individuals traveling to the second system. The multiple tracks stopped partway, and only one individual made the $90 \mathrm{~m}$ journey from one system to the other.

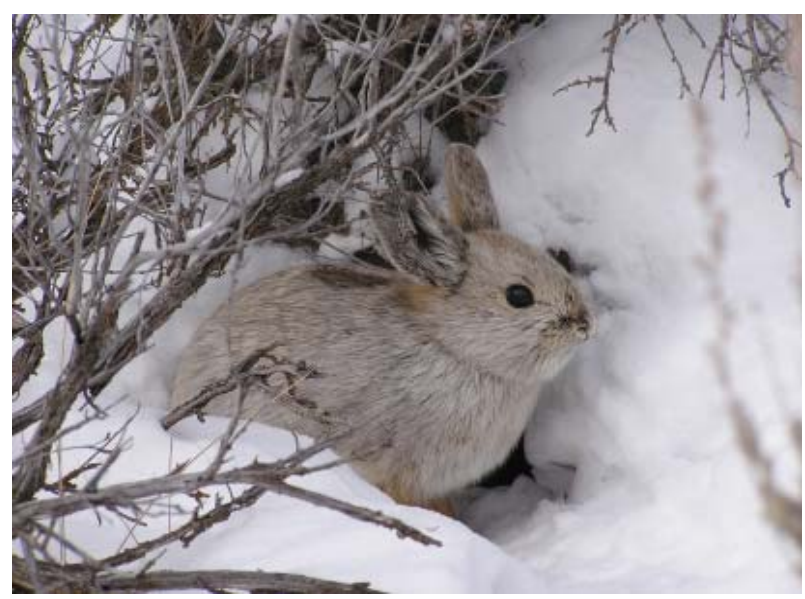

Figure 6. Pygmy Rabbit at an entrance to its burrow system in the Grasshopper Creek site (Site 3).

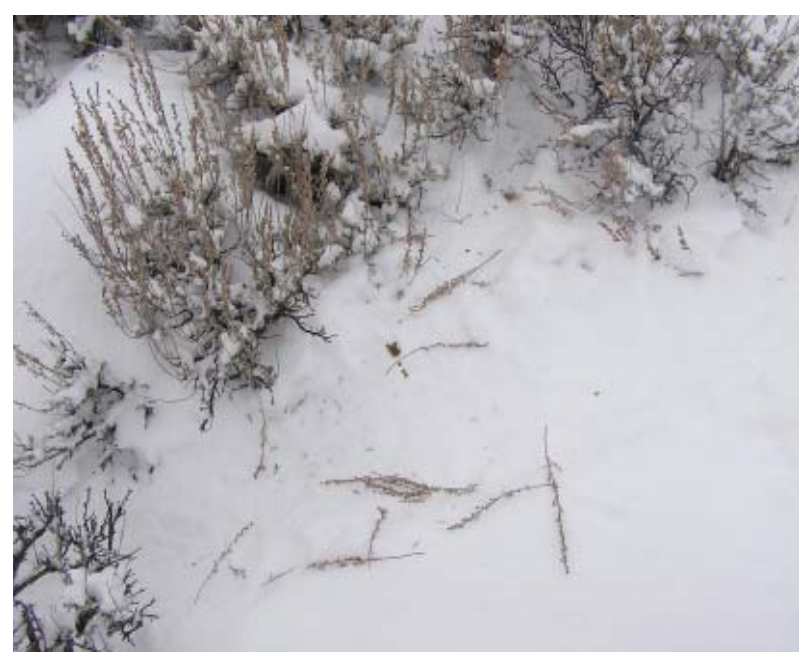

Figure 7. Sign of Pygmy Rabbit activity at Grasshopper Creek (Site 3). Included are sagebrush floret clippings, fresh pellets, urine stains, and fresh tracks. 


\section{Discussion}

\section{Bats}

The results of our bat surveys are perhaps the most significant for filling distributions gaps, with 13 first county records, including six first county records for three BLM Sensitive Species. These occurred largely in two central-Montana counties: Garfield (five bat species documented for the first time) and Petroleum (seven bat species documented for the first time). These results highlight the value of conducting surveys (especially acoustic surveys) in regions lacking species records for bats. Acoustic technology has great potential to provide rapid assessment of species distributions over many sites and identify areas of significant concentrations of species and individuals. A substantial quantity of data can be gathered relatively quickly by a small number of field personnel, making this kind of survey effort perhaps the most cost-effective for filling large distribution holes.

\section{Terrestrial Small Mammals}

Trapping terrestrial small mammals is more laborintensive than documenting the presence of bats. The results may be relatively unimpressive if the primary objective is to fill gaps in distributions of terrestrial species of conservation interest or are relatively rare. Although we captured some rodent species not overly abundant, and filled some holes in their distributions, none of the species we captured was on any state or federal animal species of concern list. We had hoped to capture some of the rarer shrews in Montana, such as Dwarf Shrew, Merriam's Shrew, and/or Preble's Shrew, all of which have been documented previously in sagebrush habitat. These species are most easily captured in pitfall traps. However, the number of nights of trapping required to capture even one of these rarer shrews may be substantial. In Wyoming for example, 338,440 pitfall trap-days at one site resulted in the capture of 5 Dwarf Shrews, 8 Merriam's Shrews, and 7 Preble's Shrews (Kirkland et al. 1997). Pitfall trap efficiency can be increased through use of drift fences, as we attempted in 2006 without success, but more time is required to set these up, and they need to be left in place for many more days than we had available. While the amount of trapping effort required to capture rare shrews may not always be as substantial as at the Wyoming site, conducting targeted surveys for shrews of conservation interest will generally require significant investment in time and personnel, or the use of methods now considered unethical (drowning animals in pitfall traps filled with toxic preservative, and left untended for many days or weeks).

\section{Pygmy Rabbits}

Our winter 2007 survey indicated few to no Pygmy Rabbits remain (if they were ever there) along the eastern and northern sides of the Pioneer Mountains (see Figure 5). Nor is it likely they occur in the area between the Pioneer Mountains and Twin Bridges. Possibly-suitable habitat in these areas is often fragmented and limited in total extent. In the eastern edge of the Big Hole Valley, on the west side of the Pioneer Mountains, we found three active sites, including reconfirming the northern-most documented in Montana (just across the Big Hole River in Deer Lodge County). Two of these active sites were first discovered in 1997 (Rauscher 1997), so it is encouraging that Pygmy Rabbits continue to persist at these seemingly isolated locations a decade after their discovery. The two new active sites we found during our survey (including one in Grasshopper Valley along the southern end of the Pioneers) occurred in large gaps between other locations, and suggest that Pygmy Rabbits may exist at additional locations in the Big Hole Valley between those currently documented. We further suggest the continued occupancy of older-known Pygmy Rabbit locations along the east side of the Big Hole Valley may actually be aided through connectivity with populations farther to the south in Grasshopper Valley, Argenta Flats, and Horse Prairie. 


\section{RECOMMENDATIONS}

\section{Bats}

The modification of landscapes is often considered the major cause of population fluctuations of many bat species. Measures for the conservation of bats frequently rely on knowledge of specieshabitat relationships, and distribution maps are often used to assess a species status. Thus, a thorough knowledge of bat distributions as they relate to habitat features is a critical base from which to direct and implement management and conservation activity.

We suggest additional surveys (especially acoustical surveys, using bat detectors) be conducted in areas of Montana where large gaps in distributions of bats coincide with BLM land holdings. Five large areas remain with essentially no records of bats (Figure 3). These include 1) Fallon and Wibaux counties, 2) northeastern Montana, including Daniels, Roosevelt and Sheridan counties, as well as northern Blaine, Phillips and Valley counties 3) Garfield, McCone, northern Prairie, and northern Rosebud counties away from the Missouri and Yellowstone rivers, 4) Golden Valley and Wheatland counties, and 5) Liberty, Pondera and Toole counties. Of these five, areas 2, 3 and 5 have the most substantial holdings of BLM lands, and the Sweet Grass Hills and Marias River corridor in area 5 may represent the largest amount of "high quality" bat habitat (upland conifer forest and riparian forest) yet to be surveyed in these large-landscape distributiongaps. At least four BLM Sensitive bat species (Townsend's Big-eared Bat, Western Long-eared Myotis, Fringed Myotis, Long-legged Myotis) are likely to occur in this area. Thus, we consider bat surveys of the Sweet Grass Hills and Marias River corridor as highest priority, and encourage the BLM to conduct or fund surveys for bats there in the near future.

\section{Terrestrial Small Mammals}

The number of non-fur bearer terrestrial small mammals currently on the BLM Sensitive Species list that could benefit from additional intensive trapping is one, the Great Basin Pocket Mouse
(Perognathus parvus). The range of this species is essentially restricted to Beaverhead County (see Hendricks and Roedel 2002). It has been caught in all kinds of traps, but may best be captured in live traps baited with seed, or pitfall arrays. The distribution in Beaverhead County and adjacent areas, where there are substantial expanses of BLM lands, is poorly defined; there are fewer than 15 location records for Montana.

Three species of shrews (Dwarf, Merriam's, Preble's) formerly listed by the BLM as Sensitive (dropped due to lack of data that could be used to affect management activity) remain poorly documented. All are broadly distributed across Montana east of the Continental Divide (Foresman 2001), and Preble's Shrew is also known to occur west of the Continental Divide (Foresman 2001, Hendricks and Roedel 2002, Hendricks unpublished data). All are associated with sagebrush habitat, but not necessarily restricted to it, and likely occur on BLM holdings in many areas of Montana. These three shrew species probably merit listing as BLM Sensitive Species, so additional distribution and habitat data for them is highly desirable.

Detecting the presence of these three shrew species will generally require significant investment of labor and time. However, it might be worth conducting targeted surveys in areas of appropriate habitat receiving other management attention, where traps may be left in place for long periods of time, but checked twice or more daily (in the case of pitfalls and live traps). In situations where this kind of localized and intensive trapping is not possible, collection and examination of raptor pellets may reveal the occasional skull remains of a rare shrew (for example, see Hendricks 2001). Therefore, we recommend the routine collection and examination of raptor pellets from nest sites of species that include shrews in their diets (for example, Northern Harrier, Red-tailed Hawk, Great Horned Owl), as well as inspection of fence rows for pellets deposited below posts where raptors perch. Over time, this may prove a useful and costefficient method for determining the presence of 
rare shrews. Skull remains of shrews can often be identified using available keys, such as Junge and Hoffmann (1981) and Carraway (1995), but should be verified by an expert.

\section{Pygmy Rabbits}

A clearer picture of the distribution and status of Pygmy Rabbits in Montana has resulted from surveys during the last decade (Rauscher 1997, Lenard et al 2005). Nevertheless, the full extent of their distribution in Montana remains uncertain. The surveys we conducted early in 2007 indicate populations in the Big Hole Valley may actually be less isolated than they currently appear. Therefore, we encourage the BLM to undertake additional Pygmy Rabbit surveys along the western and southern margins of the Pioneer Mountains, including around Big Hole Pass. Other areas that would benefit from additional surveys are 1) the Centennial Valley, 2) the Jefferson River corridor north of Twin Bridges, 3) Frying Pan Basin west of Dillon, and 4) the Ruby River and Sweetwater Creek corridors.

More attention needs to be focused on habitat descriptions of occupied and unoccupied sites. Currently, our assumptions of Pygmy Rabbit habitat requirements in Montana are based largely on studies from other states. Thus, we think it desirable that future surveys include a detailed habitat description component. These kinds of data will allow for the development of habitat suitability models (e.g., Gabler et al. 2000, Simons and Laundré 2004) that can guide future survey efforts and management planning. 


\section{Literature Cited}

Adams, R. A. 2003. Bats of the Rocky Mountain West. University Press of Colorado, Boulder, CO. 289 pp.

Carraway, L. N. 1995. A key to recent Soricidae of the western United States and Canada based primarily on dentaries. Occasional Papers of the Natural History Museum, University of Kansas 175:1-49.

Carson, S., A. Messer, R. Rauscher, and S. Story. 2006. Statewide small mammal and Montana Fish, Wildlife and Parks lands vertebrate inventory project, 2006 final report. Montana Department of Fish, Wildlife and Parks, Helena, MT. 22 pp.

Foresman, K. R. 2001. The wild mammals of Montana. American Society of Mammalogists, Special Publication No. 12. 278 pp.

Gabler, K. I., J. W. Laundré, and L. T. Heady. 2000. Predicting the suitability of habitat in southeast Idaho for Pygmy Rabbits. Journal of Wildlife Management 64:759-764.

Hayes, J. P. 1997. Temporal variation in activity of bats and the design of echolocationmonitoring studies. Journal of Mammalogy 78:514-524.

Hendricks, P. 2001. A significant new record of the Pygmy Shrew, Sorex hoyi, on the Montana-Alberta border. Canadian FieldNaturalist115:513-514.

Hendricks, P., B. Maxell, S. Lenard, C. Currier, and J. Johnson. 2006. Riparian bat surveys in eastern Montana. A report to the USDI Bureau of Land Management, Montana State Office. Montana Natural Heritage Program, Helena, Montana. 13 pp. plus appendices.

Hendricks, P., and M. Roedel. 2002. Preble’s Shrew and Great Basin Pocket Mouse from the Centennial Valley Sandhills of Montana. Northwestern Naturalist 83:31-34.
Junge, J. A., and R S. Hoffmann. 1981. An annotated key to the long-tailed shrews (Genus Sorex) of the United States and Canada, with notes on Middle American Sore. Occasional Papers of the Natural History Museum, University of Kansas 94:1-48.

Kirkland, G. L., R. R. Parmenter, and R. E. Skoog. 1997. A five-species assemblage of shrews from the sagebrush-steppe of Wyoming. Journal of Mammalogy 78:83-89.

Lenard, S., P. Hendricks, C. Currier, and B. Maxell. 2005. Pygmy Rabbit distribution in Beaverhead and Madison counties. A report to the Bureau of Land Management, Dillon Field Office. Montana Natural Heritage Program, Helena, MT. 21 pp. plus appendices.

Nagorson, D. W., and R. M. Brigham. 1993. Bats of British Columbia. UBC Press. Vancouver, BC. 164 pp.

O’Farrell, M. J., and W. L. Gannon. 1999. A comparison of acoustic versus capture techniques for the inventory of bats. Journal of Mammalogy 80:24-30.

Rauscher, R. L. 1997. Status and distribution of the Pygmy Rabbit in Montana. Final Report. Montana Department of Fish, Wildlife and Parks. Helena, MT. 19 pp. plus appendices.

Roberts, H. B. 2001. Survey of Pygmy Rabbit distribution, number and habitat use in Lemhi and Custer counties. BLM Technical Bulletin No. 01-11.

Simons, E. M., and J. W. Laundré. 2004. A largescale regional assessment of suitable habitat for Pygmy Rabbits in southwestern Idaho. Northwest Science 78:33-41. 
Ulmschneider, H. 2003. Surveying for Pygmy

Rabbits. Owyhee Field Office, Bureau of Land

Management. Unpublished document-initial

draft April 2003. 10 pp.

van Zyll de Jong, C. G. 1985. Handbook of

Canadian mammals. 2. Bats. National

Museum of Natural Sciences. Ottawa, ON.

212 pp. 